\title{
Aspek Pragmatisme Dalam Kebijakan Pintu Terbuka Jerman terhadap Pengungsi Timur Tengah: Solusi Grey Population
}

\author{
Nadia Khansa Salsabila \\ Universitas Airlangga
}

\begin{abstract}
ABSTRAK
Pada tahun 2015, krisis pengungsi yang terjadi di Uni Eropa akibat perang di Timur Tengah melatarbelakangi pengambilan kebijakan pintu terbuka Jerman. Dalam perjalanannya, kebijakan pintu terbuka menuai kontroversi dengan adanya kritik keras dari internal negara dan opini negatif publik, namun demikian kebijakan tersebut dipertahankan. Hal ini memunculkan pertanyaan terkait dasar legitimasi Jerman dalam mempertahankan kebijakan pintu terbuka yang selama ini selalu menonjolkan sisi dan ide-ide humanitarianisme. Oleh karena itu, penelitian ini berusaha melihat aspek lain dalam kebijakan pintu terbuka sebagai kebijakan luar negeri Jerman, yaitu aspek pragmatisme berdasarkan konsiderasi persoalan demografi terkait grey population yang berdampak negatif pada stabilitas dan prospek perekonomian Jerman. Berdasarkan pemikiran tersebut, penulis memiliki argumen bahwa alasan Jerman mengambil dan mempertahankan kebijakan pintu terbuka adalah sebagai solusi untuk membantu mengatasi persoalan grey population dalam konteks demografi dan ekonomi. Kebijakan pintu terbuka dapat menjadi solusi grey population melalui pemanfaatan pengungsi, yang termasuk imigran, sebagai tenaga kerja produktif dan tax payer di Jerman.
\end{abstract}

Kata Kunci: Kebijakan Pintu Terbuka, Jerman, Pengungsi, Timur Tengah, Pragmatisme, Grey Population, Imigran, Tenaga Kerja Produktif, Tax Payer

In 2015, refugee crisis that occurred in European Union due to the war in the Middle East formed the background of Germany's open-door policy. As it is implemented, this open-door policy attracted several controversies with strong internal criticism and negative public opinion, but the policy still be maintained. This phenomenon raises questions regarding on the basis of German legitimacy in maintaining an open-door policy which has always highlighted the sides and ideas of humanitarianism. Therefore, this study seeks to see other aspects of Germany's open-door policy as German foreign policy, namely 'pragmatism' based on consideration of demographic issues related to greying population which have a negative impact on German's stability and economic prospects. Based on these thoughts, the author argues that Germany maintained the open-door policy as a solution to help overcome greying population in demographic and economic context. The open-door policy can be use as a solution through the use of refugees and immigrants as productive workers and tax payers in Germany.

Keywords: Open Door Policy, Germany, Refugees, Middle East, Pragmatism, Grey Population, Immigrants, Productive Workers, Tax Payer. 


\section{Pendahuluan}

Pengambilan kebijakan pintu terbuka Jerman (open-door policy) dilatarbelakangi oleh krisis pengungsi yang terjadi di Uni Eropa akibat terjadinya perang di Timur Tengah. Konflik antara pemerintah Bashar al-Assad dan berbagai kekuatan lain di Suriah, yang dimulai pada tahun 2011, terus menyebabkan perpindahan dari dalam negara ke wilayah lain. Konflik dipicu oleh demonstrasi oposisi yang menuntut reformasi demokratis dan jatuhnya rezim Assad. Situasi yang disebabkan oleh konflik Suriah kemudian memunculkan krisis pengungsi Suriah dan menempatkan tekanan pada negara-negara tetangga seperti Lebanon, Yordania, Irak, Mesir, dan Turki yang menjadi penampung sebagian besar pengungsi (Ostrand 2015). Suriah lebih jauh lagi mencari perlindungan di luar negaranegara tersebut dalam jumlah yang semakin meningkat sejak tahun 2011. Dengan jumlah kelompok Negara Islam (Islamic State) yang melakukan teror terhadap Irak dan Suriah, perang sipil Suriah seperti berkecamuk tanpa akhir, ditambah dengan memburuknya situasi bagi pengungsi di Yordania dan Lebanon semakin mendorong keputusan banyak orang di Timur Tengah untuk melarikan diri ke Uni Eropa dalam upaya mencari suaka.

Kedatangan mereka menguji kemampuan negara anggota Uni Eropa untuk merespon krisis dengan barisan persatuan meskipun akhirnya gagal. Akibat ketidakmampuan Uni Eropa secara kolektif menangani pendatang, negara-negara mulai menutup perbatasan secara unilateral (Mayer 2016). Bahkan Swedia yang awalnya menerima lebih banyak pengungsi per kapita dibandingkan negara lain, memperkenalkan kebijakan pembatasan mengenai suaka dan menutup perbatasannya pada tahun 2015. Pada akhirnya, Jerman menjadi negara Uni Eropa yang mempromosikan kebijakan pintu terbuka dan memutuskan untuk tetap terlibat dalam kebijakan pintu terbuka sejak awal pengungsi datang ke Eropa. Kanselir Merkel secara optimistis berpegang pada pernyataannya "Wir schaffen das" atau "We can do this" dalam menghadapi krisis pengungsi yang terjadi. Perang di Timur Tengah, terutama Suriah, menggerakkan pemerintah Jerman untuk memberikan perlindungan kepada pengungsi yang disebut Merkel sebagai 'tugas nasional'. Jerman memang diketahui telah melakukan pemberian suaka jauh lebih banyak dibandingkan negara Eropa lainnya.

Washington Post melaporkan bahwa ikrar publik Merkel mengenai Jerman yang akan menawarkan tempat tinggal sementara bagi para pengungsi yang tiba di negaranya mendorong peningkatan jumlah kedatangan pengungsi melalui jalur Balkan. Pernyataan 
Merkel yang terkenal, "Wir schaffen das", telah menjadi kredo sikap terbuka dan kemanusiaan pemerintah Jerman krisis pengungsi. Pada tahun 2016, dalam jangka waktu seminggu, Jerman diguncang oleh tindakan penyerangan berdarah di sebuah kereta api, penembakan massal di Munich, machete attack, dan bom bunuh diri di Ansbach (Dockery 2017). Tiga dari serangan tersebut dilakukan oleh para pengungsi dan terdapat serangan yang diyakini memiliki motif ekstremis. Serangan-serangan merisaukan yang terjadi menyebabkan kebijakan pintu terbuka dipertanyakan dan semakin mendapat pertentangan. Meskipun demikian, Kanselir Merkel menunjukkan pembelaannya dengan bersikeras menyatakan bahwa, dalam menanggapi serangkaian penyerangan yang terjadi, tidak ada penyesalan atas keputusan mengambil kebijakan tersebut sejak awal. Mengulangi mantra "Wir schaffen das", Merkel menekankan bahwa penerapan kebijakan memang tidak akan mudah, justru menjadi tantangan yang dapat menjadi tugas bersejarah tersebut sejauh ini dapat dikelola (Connolly 2016).

Merkel menghadapi kritik keras dari pejabat Jerman setelah kebijakannya menyebabkan satu juta orang memasuki Jerman pada tahun 2015. Sebuah studi oleh Yayasan Bertelsmann Jerman mengklaim bahwa mayoritas masyarakat Jerman merasa bahwa negara mereka tidak dapat mengatasi peningkatan imigran lebih lanjut (Wood 2017). Dari penelitian yang dilakukan, terungkap adanya perbedaan pendapat yang cukup signifikan antara Jerman Timur dan Barat mengenai penerimaan pengungsi. Kenyataan bahwa Jerman menyusun anggaran keuangan yang cukup besar untuk masalah pengungsi juga membangun opini publik bahwa kebijakan pintu terbuka hanya merugikan Jerman. Terlebih lagi, serangkaian penyerangan telah memunculkan sentimen negatif masyarakat terhadap pengungsi. Merkel semakin mendapatkan tekanan, bahkan dari partainya sendiri, karena tampaknya tidak mungkin pula untuk terus menampung dan mengintegrasikan lebih dari satu juta pengungsi yang memasuki Jerman. Seiring berjalannya waktu, beberapa aspek undang-undang mengenai suaka Jerman telah diperketat meskipun kebijakan pintu terbuka terhadap mereka yang membutuhkan perlindungan tetap diterapkan (Mayer 2016).

Terdapat anomali dari sikap terbuka Jerman melalui kebijakan pintu terbuka yang tetap dipertahankan di saat negara-negara Uni Eropa lain mulai menutup diri dan di tengah kritik serta pertentangan internal negara dan menuai opini negatif publik. Keunikan tersebut memunculkan pertanyaan terkait dasar legitimasi Jerman, khususnya Kanselir Merkel, dalam mempertahankan kebijakan pintu terbuka yang selama ini selalu menonjolkan sisi dan ide-ide hu- 
manitarianisme. Oleh sebab itu, penulis kemudian berusaha untuk melihat dan menjelaskan salah satu kemungkinan alasan lain yang mendasari pengambilan dan dipertahankannya kebijakan pintu terbuka Jerman, yaitu aspek pragmatis terkait isu demografi yang berimplikasi pada perekonomian negara.

\section{Isu Grey Population dan Kebijakan Pintu Terbuka Jerman}

Permasalahan kependudukan menjadi masalah utama yang dihadapi Jerman. Tiga tren yang menandakan perkembangan demografi Jerman adalah: angka kelahiran rendah, meningkatnya usia harapan hidup, dan kondisi masyarakat yang menua (Fakta Mengenai Jerman t.t) Angka kelahiran tertinggi Jerman terjadi pada tahun 1967 dengan 1.357 juta kelahiran dan selanjutnya terus mengalami penurunan. Seperti pada tahun 1990-an tercatat sekitar 900.000 kelahiran, hingga tahun 2014 hanya tercatat sebesar 715.000 kelahiran. Generasi anak-anak berjumlah sepertiga lebih kecil dibandingkan dengan generasi dewasa. Bersamaan dengan hal tersebut, meningkat pula usia harapan hidup dengan rata-rata usia harapan hidup laki-laki 77 tahun dan perempuan 82 tahun. Para ahli demografi mengategorikan penuaan populasi di suatu wilayah ketika proporsi penduduk yang berusia lanjut dari suatu wilayah tersebut meningkat (Ortman 2014). Berdasarkan data resmi dari Kantor Statistik Federal Jerman, diketahui tren peningkatan jumlah penduduk usia 6o-80 tahun dan usia 80 tahun dan lebih. Sementara berdasarkan data proyeksi populasi Jerman, diketahui tren peningkatan persentase penduduk usia 65+ tahun, rasio ketergantungan usia tua dan umur median. Proyeksi populasi di tahun-tahun berikutnya juga memprediksi adanya peningkatan pada indikator yang sama. Dengan demikian, dapat diketahui adanya tren peningkatan proporsi penduduk usia tua, rasio ketergantungan usia tua dan umur median dari tahun ke tahun sehingga cukup menggambarkan adanya fenomena ageing population atau persoalan grey population di Jerman (Statistisches Bundesamt 2015).

Persoalan grey population di Jerman lebih lanjut berdampak negatif pada stabilitas dan perekonomian negara. Penuaan populasi tenaga kerja semakin pesat terjadi di Jerman. Berdasarkan data proyeksi populasi hingga beberapa dekade mendatang, Jerman diprediksi akan kekurangan penduduk usia produktif yang memiliki konsekuensi; pertama, pada tingkat pertumbuhan ekonomi. Pertumbuhan ekonomi tidak akan berkelanjutan mengingat populasi usia kerja yang menyusut dan selanjutnya berkaitan dengan penawaran tena- 
ga kerja dan modal (Diw Berlin 2015). Angkatan kerja yang menyusut akan mengurangi potensi output pertumbuhan ekonomi menurunkan pendapatan per kapita. Kedua, dampak negatif juga terjadi pada isu ketenagakerjaan pada tingkat domestik ketika perusahaanperusahaan bersaing untuk memperebutkan tenaga kerja. Ketiga, perubahan demografis secara langsung mengubah jumlah angkatan kerja, pola konsumsi dan tabungan dan produktivitas tenaga kerja. Keempat, peningkatan jumlah pensiunan meningkatkan permintaan untuk kualitas perawatan yang lebih baik (Philipov et al. 2014). Kesehatan penduduk usia tua adalah masalah besar di Jerman, juga karena masalah biaya yang harus dikeluarkan pemerintah terkait dengannya (Nowossadeck et al. 2014). Kondisi masyarakat yang menua juga akan meningkatkan kebutuhan penyesuaian infrastruktur untuk generasi tua. Pensiun dan layanan perawatan penduduk usia tua yang jumlahnya semakin banyak juga perlu dibiayai dan berakibat pada dampak kelima, yakni terkait dengan kebijakan fiskal. Dampak akan dirasakan pada keuangan publik dengan adanya beban fiskal yang lebih besar pada setiap individu yang bekerja karena rasio ketergantungan usia terus meningkat. Persoalan keuangan publik juga berkaitan dengan berkurangnya jumlah tax payer dengan menyusutnya populasi usia kerja produktif.

Persoalan grey population yang berimplikasi pada perekonomian negara Jerman ini kemudian memunculkan ide kebijakan pintu terbuka sebagai salah satu solusi untuk membantu mengatasi persoalan ini. Ide kebijakan pintu terbuka sebagai solusi grey population berkaitan erat dengan pengembangan demografi serta perluasan pasar tenaga kerja dan ekonomi negara. Menurunnya populasi Jerman dan meningkatnya rasio ketergantungan adalah isu inti dari tema ini. Sebagai akibatnya, pengeluaran pemerintah, misalnya untuk dana pensiun dan kesehatan, diperkirakan akan meningkat pesat dalam beberapa dekade mendatang (Hewitt 2015). Lebih lanjut lagi, Jerman diharapkan memiliki arus migran sekitar setengah juta per tahun hingga 2050 untuk mengimbangi penurunan berikutnya dalam angkatan kerja (Nasr 2015). Sebagian politisi Jerman beranggapan bahwa imigrasi penting bagi kelangsungan hidup Jerman dan bahwa mengambil sejumlah besar pengungsi akan bermanfaat bagi negara dalam jangka panjang. Mereka dapat membantu meringankan tekanan demografi yang dialami negara setelah terintegrasi ke dalam masyarakat dan pasar tenaga kerja. Para ekonom juga berpendapat bahwa imigrasi mendorong pertumbuhan dan investasi bagi perusahaan domestik swasta di berbagai bidang, seperti pendidikan, kesehatan, keamanan dan perumahan, serta akan memiliki efek yang sama seperti paket stimulus bagi perekonomian. 
Dari press release Jerman melalui situs resmi Kantor Statistik Federal dinyatakan bahwa tingginya tingkat imigrasi bersih dapat memperlambat dan membantu mengurangi tingkat penuaan populasi dari adanya grey population. Berdasarkan data, pendanaan untuk pengungsi dan pencari suaka meningkat dari sebesar 1 miliar euro di tahun 2015 menjadi 6 miliar euro di tahun 2016 (Deutscher Bundestag 2015). Jerman telah menyediakan berbagai pelayanan seperti tempat tinggal dan perawatan kesehatan. Lebih dalam kaitannya dengan solusi grey population, terdapat penyediaan berbagai program pendidikan, misalnya kelas bahasa, program pelatihan kerja dan keterampilan serta upaya-upaya untuk mempermudah integrasi ke dalam pasar tenaga kerja bagi para imigran. Beberapa laporan media internasional dan akademisi, salah satunya Matthias M. Mayer (2016) dalam tulisannya, juga menyatakan bahwa krisis demografi dan kekurangan tenaga kerja di sektor tertentu memainkan peran keterbukaan Jerman terhadap pengungsi. Para pengungsi sebagai imigran akan memberikan keseimbangan karena kebanyakan dari mereka berusia di bawah 35 tahun. Sehingga pada saat bersamaan memberikan efek positif pada pasar tenaga kerja, bukan hanya karena mereka termasuk usia produktif tetapi juga berpendidikan cukup baik, dalam hal ini terutama merujuk pada pengungsi Suriah. Mereka biasanya menciptakan lapangan kerja baru dan meningkatkan pasar tenaga kerja. Adanya imigrasi meningkatkan jumlah tax payer potensial, khususnya imigran usia kerja produktif yang berkontribusi positif terhadap pembayaran pajak bersih. Dengan demikian, ide kebijakan pintu terbuka sebagai solusi grey population dapat dijelaskan melalui pemanfaatan imigran sebagai tenaga kerja produktif atau potential workers dan tax payer di Jerman.

\section{Imigran sebagai Tenaga Kerja Produktif atau Potential Workers di Jerman}

Kondisi pasar tenaga Jerman dengan melihat dampak grey population, dapat dikatakan memberikan efek negatif karena menyebabkan adanya kekurangan tenaga kerja Jerman. Pernyataan tersebut didasarkan pada argumen bahwa pasar kerja Jerman menunjukkan lapangan kerja dan tingkat tenaga kerja tinggi dengan tingkat pengangguran rendah (Statistisches Bundesamt 2018). Apabila tren tersebut dikombinasikan dengan proyeksi populasi usia kerja dengan adanya grey population, maka sangat mungkin bahwa Jerman akan mengalami kekurangan tenaga kerja terutama di masa mendatang. Terkait perekonomian dan ketenagakerjaan dengan adanya persoalan grey population, Menteri Keuangan Jerman Wolfgang Schäuble mengatakan bahwa perubahan demografis menjadi salah satu tantangan terbesar negara (Wagstyl 2015). Dengan kuatnya 
ekonomi dan rendahnya tingkat pengangguran, populasi usia kerja menurun dan memberikan tekanan besar pada employer. Sebagai tanggapan, pemerintah Federal Jerman menaikkan usia pensiun resmi dari 65 tahun menjadi 67 tahun dan mendorong individu untuk menabung serta melakukan upaya untuk memotong pinjaman publik. Pentingnya menghindari utang baru dengan populasi yang semakin tua juga disampaikan oleh pejabat kementerian keuangan. Pada saat menjabat sebagai Menteri Tenaga Kerja dan Sosial, Ralf Brauksiepe mengemukakan bahwa masa kerja yang lebih lama dan masuknya tenaga kerja terampil dari luar negeri adalah jawaban atas bom waktu demografis Jerman (Elliott \& Kollewe 2011). Masalah populasi yang menua dan berkurang telah mendapatkan perhatian pemerintah Federal Jerman, menambahkan bahwa 41 juta tenaga kerja akan menyusut dengan cepat pada pertengahan tahun 2020an dengan tren yang ada saat ini.

Negara-negara industri maju seperti Jerman membutuhkan tenaga kerja untuk mempertahankan kemampuan produksi mereka dengan mengambil migran dari berbagai belahan dunia. Meskipun pengungsi tidak langsung diizinkan untuk mengambil bagian di pasar tenaga kerja, sebagai imigran mereka akan melakukannya dalam jangka panjang. Pada pembahasan sebelumnya, telah disebutkan bahwa kebijakan pintu terbuka Jerman mencakup penyediaan anggaran termasuk untuk berbagai program pendidikan. Pemerintah Jerman juga berencana menyediakan beberapa ribu one-euro jobs atau pekerjaan satu euro dalam rangka memperkenalkan pendatang baru ke pasar tenaga kerja Jerman secara perlahan. ${ }^{1}$ Pekerjaan ini sendiri merupakan kategori baru pekerjaan dengan upah rendah untuk mereformasi sistem kesejahteraan sosial Jerman dan membantu mengatasi pengangguran jangka panjang (Tzortzis 2004). Pengungsi-sebagai tenaga kerja imigran-secara berlanjut terus diupayakan untuk diintegrasikan ke dalam pasar tenaga kerja Jerman. Masuknya pengungsi sebagai imigran usia kerja produktif, terutama pekerja terampil muda, dipandang sebagai peluang bisnis. Oleh karena tingkat pengangguran Jerman yang rendah, beberapa sektor ekonomi dan perusahaan tidak dapat memenuhi kekosongan pekerjaan tertentu, sehingga mengakibatkan semakin tingginya permintaan terhadap tenaga kerja. Hal tersebut kemudian dapat diselesaikan salah satunya dengan masuknya para pengungsi, terutama untuk golongan usia produktif (Copley 2016).

1 One-euro jobs memiliki batasan masa kerja sebanyak 15-30 jam seminggu dan tidak lebih dari tiga bulan hingga enam bulan, bayaran sekitar 1 euro hingga 3 euro per jam, dan menerima maksimum 180 euro dalam sebulan (Tzortzis 2004). Sumber: https://www.dw.com/en/one-euro-one-way-out-of-unemployment/a-1416143. 
Besarnya kepentingan pemerintah Federal Jerman terhadap keberadaan imigran untuk mengisi kebutuhan tenaga kerja ditunjukkan dengan strategi nasional yang dilakukan. Sebagaimana yang telah dijelaskan sebelumnya, terdapat fakta mengenai dinamika tenaga kerja produktif yang semakin menurun. Masuknya pengungsi sebagai imigran dipandang sebagai kesempatan bagi Jerman untuk mengisi angkatan kerja dan menjadikan mereka tenaga kerja produktif atau potential workers. Oleh sebab itu, muncul upaya integrasi ke pasar tenaga kerja Jerman melalui: (1) kelas bahasa Jerman dan kursus integrasi, (2) integrasi angkatan kerja melalui pelatihan kejuruan atau keterampilan kerja, dan (3) jalur lain integrasi angkatan kerja melalui pekerjaan berketerampilan rendah, pendidikan tinggi dan upaya program oleh masyarakat sipil dan organisasi relawan. Pada dasarnya, strategi integrasi imigran ini melibatkan pemangku kepentingan (stakeholder) utama dalam kebijakan integrasi Jerman pada tingkat federal, regional dan kota (OECD 2017).

Struktur Federal Jerman menambahkan kerumitan dalam pengaturan yang kompleks. Pemerintah federal sebagian besar bertanggung jawab untuk menetapkan kerangka hukum untuk integrasi, misalnya mendirikan kursus bahasa atau mempermudah akses ke pasar tenaga kerja, sedangkan negara federal (länder) ditugaskan dalam implementasi konkret (OECD 2017). Sementara pemerintah kota merupakan aktor penting dalam proses integrasi, yang melakukan kebijakan terutama ketika undang-undang terbuka untuk interpretasi atau bertentangan dengan bagian lain dari hukum. The Federal Office for Migration and Refugees (Bundesamt für Migration und Flüchtlinge atau BAMF) berafiliasi dengan Kementerian Dalam Negeri dan bertanggung jawab untuk menilai permohonan suaka dan mendesain dan mengimplementasikan kursus bahasa umum dan kejuruan (OECD 2017). Kursus bahasa dilaksanakan oleh penyedia pendidikan lokal, seperti pusat pendidikan orang dewasa atau sekolah bahasa yang harus diakreditasi di BAMF. Oleh sebab itu, agensi tersebut memiliki peran ganda: memproses permohonan suaka; dan mendukung integrasi para migran.

The Federal Employment Agency (Bundesagentur für Arbeit atau BA) berada di bawah pengawasan Kementerian Tenaga Kerja dan Sosial dan memiliki peran kunci dalam mendukung pencari suaka dan pengungsi untuk mencari pekerjaan dan meningkatkan keterampilan profesional (OECD 2017). Terdapat pula Employment Agencies pada tingkat lokal untuk memberikan layanan yang dibiayai oleh kontribusi asuransi pengangguran dan hanya dapat diakses oleh mereka yang telah membayar keuntungan jaminan sosial. Employment Agencies ini juga bertanggung jawab atas integrasi 
tenaga kerja selama proses suaka. Ada pula Jobcenters di Jerman yang dijalankan oleh kota sendiri atau bersama dengan Employment Agencies lokal kota. Jobcenters menyediakan layanan integrasi pasar tenaga kerja untuk pengangguran jangka panjang dan penerima keuntungan sistem kesejahteraan sosial serta bagi para pengungsi. Jobcenters memiliki tawaran pekerjaan dan selanjutnya berkaitan dengan penempatan tenaga kerja (Dettmer et al. 2015). Pengungsi sendiri memiliki hak untuk melakukan konsultasi atau menanyakan saran ke Jobcenters dan ditempatkan ke pasar tenaga kerja. Dengan demikian, keberadaan Jobcenters menjadi sangat signifikan bagi pengungsi.

\section{Imigran sebagai Tax Payer di Jerman}

Imigran sebagai tax payer di Jerman merupakan kelanjutan dari imigran sebagai tenaga kerja produktif atau potential workers. Hal ini dikarenakan pajak terbesar biasanya dibayarkan oleh tenaga kerja yang produktif. Kebijakan pintu terbuka menjadi bagian dari strategi pragmatis Jerman utuk mengatasi grey population, dengan argumen bahwa pengungsi - terutama usia muda dan tenaga kerja produktif - dapat ikut berkontribusi pada ekonomi negara dengan membayar pajak. Pajak sendiri memiliki peran penting dalam mendorong pertumbuhan dan menopang ekonomi Jerman. Pajak berkontribusi pada penawaran total sehingga memperluas aktivitas ekonomi yang akhirnya mendorong pertumbuhan ekonomi (Häuser 1966). Pajak yang dibayarkan ke Jerman itulah yang akan digunakan untuk melaksanakan sistem kesejahteraan Jerman itu sendiri. Dengan demikian, pajak memiliki kontribusi signifikan terhadap ekonomi Jerman. Penerapan sistem pajak berbeda-beda di setiap negara. Begitu pula dengan aturan pajak Jerman yang berbeda dengan aturan di negara lain. Pemungutan pajak di Jerman dilakukan oleh pemerintah federal (Bund), negara bagian (Länder) dan kota (Städte/Gemeinden). Banyak pajak langsung dan tidak langsung berlaku di Jerman. Sekitar 95\% dari semua pajak dikenakan pada tingkat federal. Sebagian besar pendapatan pajak diperoleh dari pajak penghasilan.

Pada tahun 2017, pajak penghasilan menyumbang sebesar 25\% dari total pendapatan pajak Jerman berdasarkan tipe pajak. Jerman memiliki sistem pajak progresif. Artinya, untuk euro pertama dari penghasilan yang didapatkan, maka sudah harus mulai membayar pajak yang sangat rendah di awalnya. Jumlah pajak akan semakin meningkat mengikuti persentase euro yang dihasilkan. Tarif pajak rata-rata meningkat secara monoton dengan peningkatan pendapatan kena pajak. Tingkat pajak penghasilan di Jerman berkisar dari 
o\% hingga 45\% sebagai tingkat pajak maksimum (Scheller 2014). Setiap individu juga diharuskan membayar untuk tunjangan yang diterima dari employer. Selain itu, terdapat pula biaya tambahan solidarity surcharge (Solidaritätszuschlag) dan pajak gereja. Solidarity surcharge merupakan pajak hingga 5,5\% dari pajak penghasilan yang diperkenalkan untuk membayar reunifikasi Jerman, termasuk utang dan kewajiban pensiun dari pemerintah Jerman Timur serta biaya perbaikan infrastruktur dan lingkungan di negara-negara bagian baru Jerman (Scheller 2014). Sementara pajak gereja sebesar $8 \%$ atau 9\% jika wajib pajak mendaftar dengan gereja Jerman. Sistem pajak di Jerman ini diberlakukan sama, baik pada penduduk asli Jerman maupun imigran atau warga asing yang bekerja di Jerman. Imigran termasuk subjek pajak yang memiliki kewajiban membayar pajak di Jerman atas penghasilan yang berasal dari sumber Jerman (limited tax liability) (KPMG 2018). Kewajiban pajak telah dipenuhi dengan pemotongan penghasilan atau pajak upah, sehingga tidak ada pengembalian pajak yang perlu diajukan.

Imigran sebagai tenaga aktif produktif secara ekonomi dapat berkontribusi terhadap negara secara ekonomi dengan membayar pajak. Imigran sebagai tenaga kerja di Jerman akan dikenakan kewajiban pembayaran pajak, dalam hal ini khususnya pajak penghasilan, sebagaimana tenaga kerja atau karyawan Jerman lainnya. Dalam kaitannya dengan imigran sebagai tax payer di Jerman, terdapat pernyataan yang bisa didapatkan dari pejabat pemerintah Federal Jerman. Menteri Keuangan Wolfgang Schäubel menekankan bahwa Jerman tidak ingin menambah utang dengan meminjam uang sehingga lebih memilih untuk mempertahankan anggaran berimbangnya saat ini hingga tahun 2020 (Dettmer \& Reiermann 2016). Schäuble memiliki solusi untuk menutup lubang-lubang anggaran pemerintah dan ekonomi negara Jerman setidaknya sebagian melalui pendapatan pajak siklikal, termasuk dari pembayaran pajak penghasilan imigran yang menjadi tenaga kerja produktif di Jerman. Hal ini dikarenakan umumnya pajak berasal dari pembayaran tenaga kerja produktif, sehingga dalam hal ini imigran sebagai tenaga kerja produktif menjadi subjek pajak Jerman atas penghasilannya yang didapatkan di Jerman. Dengan demikian, terdapat kepentingan Jerman terkait kontribusi imigran sebagai tax payer sebagai kelanjutan dari keberadaan imigran sebagai tenaga kerja produktif di Jerman

Keuntungan kesejahteraan Jerman dengan adanya imigrasi dapat diketahui dari fakta bahwa imigrasi dapat meningkatkan penawaran tenaga kerja yang berimbas pada kenaikan tingkat employment, produksi dan PDB (Ortega \& Peri 2009). Imigrasi meningkatkan 
produktivitas ekonomi Jerman melalui kontribusi imigran sebagai tenaga kerja dan aktif secara ekonomi, sedangkan peran mereka sebagai tax payer akhirnya menentukan kontribusi mereka terhadap sistem kesejahteraan negara ini (welfare state system). Proyeksi populasi Jerman dari tahun 2016 hingga 2035 menghasilkan dampak perubahan demografis terhadap beberapa indikator ekonomi Jerman (Beznoska \& Hentze 2017). Salah satu poin penting yang dapat ditilik adalah pendapatan pajak mengalami penurunan sebesar 6,6\%. Namun, masuknya pengungsi sebagai bagian dari imigrasi menjadi solusi untuk mengatasi dampak grey population terhadap ekonomi Jerman. Imigran yang menjadi tenaga kerja produktif dan sebagai tax payer dapat berkontribusi positif terhadap pertumbuhan ekonomi Jerman. Hal tersebut dapat dilihat pada proyeksi perubahan dalam PDB tahunan negara ini yang menunjukkan tren mengalami peningkatan sebagai hasil dari adanya migrasi pengungsi ke Jerman (World Education Services 2017). Proyeksi peningkatan PDB ini secara tidak langsung juga berdampak pada peningkatan jumlah pembayaran pajak ke Jerman, misalnya dari pajak penghasilan termasuk dari imigran dan pengunngsi.

Orang asing di Jerman nyatanya berkontribusi lebih banyak. Sebuah penelitian di Jerman menemukan bahwa bertentangan dengan persepsi publik, imigran bukanlah beban keuangan publik, tetapi justru membawa hampir 22 miliar euro dalam setahun (Bölinger 2014). Imigrasi menjadi topik hangat di Jerman, dalam hal ini berfokus pada masuknya pengungsi dari Timur Tengah. Sebagaimana negara ini berjuang mengatasi jumlah pencari suaka yang belum pernah terjadi sebelumnya. Sebuah studi oleh Yayasan Bertelsmann mengenai analisis cost-benefit imigrasi menemukan fakta bahwa imigran adalah kontributor bersih untuk keuangan publik. Selain itu, diketahui bahwa rata-rata warga asing yang tinggal di Jerman membayar sebesar 3.300 euro lebih banyak dari pajak setiap tahun daripada yang diterima dalam tunjangan (Bölinger 2014). Dengan anggapan umum 6,6 juta warga asing yang tinggal di Jerman, berarti imigran menyumbang 21,78 miliar euro setiap tahun ke ekonomi pemerintah Jerman. Meskipun pembayaran pajak rata-rata oleh warga negara asing lebih rendah dibandingkan orang Jerman, hampir $67 \%$ dari imigran adalah kontributor bersih dibandingkan hanya $60 \%$ orang Jerman (Huggler 2014). Sehingga dapat disimpulkan bahwa Jerman secara finansial mendapatkan banyak keuntungan dari populasi asingnya.

Pada akhirnya, pengeluaran untuk mengintegrasikan pengungsi merupakan investasi di masa depan. Masuknya arus pengungsi Timur Tengah pada tahun 2015 terjadi pada momen yang berte- 
patan dengan sehatnya ekonomi Jerman dan kuatnya pasar tenaga kerja Jerman yang membutuhkan banyak angkatan kerja. Pada saat yang sama, pengeluaran pemerintah untuk pengungsi lebih dari sekedar biaya yang dikeluarkan, namun justru memiliki efek positif bagi perekonomian negara (Dettmer \& Reiermann 2016). Alasannya adalah hanya sebagian dari dana tersebut yang langsung diperuntukkan kepada para pengungsi, sebagian lainnya dipompa langsung ke dalam ekonomi. Dana pemerintah yang dibayarkan kepada para pengungsi sering kembali ke ekonomi dalam bentuk pembelanjaan konsumen, yang akhirnya dapat menyebabkan pertumbuhan ekonomi. IMF menghitung bahwa peningkatan belanja pemerintah akan meningkatkan pertumbuhan ekonomi di Jerman, dan mengharapkan bahwa perkembangan pengungsi di Jerman akan menyebabkan peningkatan antara $0,5 \%$ dan $1,1 \%$ dalam pertumbuhan ekonomi tambahan, dengan asumsi bahwa negara tersebut berhasil mengintegrasikan imigran ke pasar tenaga kerja (Dettmer \& Reiermann 2016). Lebih jauh lagi, imigran yang menjadi tenaga kerja produktif lebih lanjut berkontribusi terhadap ekonomi sebagai tax payer di Jerman. Dengan demikian, apabila hal tersebut berhasil dilakukan, imigran akan membantu membiayai negara Jerman dalam bentuk pajak.

\section{Kesimpulan}

Dari pemaparan di atas, dapat disimpulkan bahwa terdapat adanya keterkaitan antara kebijakan pintu terbuka Jerman dengan aspek pragmatis negara terkait demografi, dalam hal ini persoalan grey population yang dialami Jerman. Grey population memiliki korelasi negatif dalam konteks demografi terkait komposisi penduduk terutama usia produktif dan konteks ekonomi terkait ketenagakerjaan. Dengan adanya persoalan grey population, populasi penduduk usia produktif sebagai angkatan kerja akan semakin berkurang seiring dengan kondisi masyarakat Jerman yang menua. Persoalan tersebut menjadi penting karena lebih lanjut menyebabkan peningkatan ketergantungan usia tua dan beban pensiun serta persoalan kekurangan tenaga kerja terutama usia produktif. Hal ini memunculkan kepentingan Jerman atas keberadaan imigran, yang sebagian besar termasuk dalam usia produktif, sebagai tenaga kerja produktif atau potential workers untuk meningkatkan produktivitas dan menggerakkan roda perekonomian negara dan, lebih lanjut, tax payer di Jerman sebagai salah satu sumber pemasukan negara Jerman untuk membiayai operasionalisasi negara ini. Kebijakan pintu terbuka yang mendatangkan pengungsi sebagai imigran akhirnya menjadi bagian dari strategi pragmatis Jerman dalam upayanya mengatasi grey population. 


\section{Daftar Pustaka}

\section{Artikel Jurnal}

Beznoska, Martin and Tobias Hentze, 2017. "Demographic Change and Income Tax Revenue in Germany: A Microsimulation Approach", Public Sector Economics, 41 (1): 71-84.

Mayer, Matthias, 2016. "Germany's Response to the Refugee Situation: Remarkable Leadership or Fait Accompli?” [online] in http://www.bfna.org/research/germanys-response-to-therefugee-situation-remarkable-leadership-or-fait-accompli/ [diakses 4 Maret 2018].

Nowossadeck, Sonja, et al., 2014. "Ageing in Germany: Content, Quality and Accessibility of Relevant Data Sources" [online] in https://www.dza.de/fileadmin/dza/pdf/Diskussionspapier_Nr_56.pdf [diakses 31 Agustus 2018].

OECD, 2017. Finding Their Way: Labour Market Integration of Refugees in Germany in https://www.oecd.org/els/mig/Findingtheir-Way-Germany.pdf [diakses 14 November 2018].

Ostrand, Nicole, 2015. "The Syrian Refugee Crisis: A Comparison of Responses by Germany, Sweden, the United Kingdom, and the United States", Journal on Migration and Human Security, 3(3).

Philipov, Dimiter, et al., 2014. "Ageing dynamics of a human-capital-specific population: A demographic perspective”, Demographic Research, 31(44): 1311- 1336.

\section{Laporan Tahunan}

Ortega, Fransesc and Giovanni Peri, 2009. "The Causes and Effects of International Labor Mobility: Evidence from OECD Countries 1980-2005", Human Development Research Paper, No. 6, United Nations Development Program (UNDP), New York.

Ortman, Jennifer M., et al., 2014. "An Aging Nation: The Older Population in the United States; Current Population Reports", Current Population Reports P25-1140. Washington, DC: US Bureau, Population Projections Branch. 


\section{Publikasi Resmi}

Deutscher Bundestag, 2015. "Plenarprotokoll 18/139 - Stenografischer Bericht 139" [online] in http://dip21.bundestag.de/ dip21/btp/18/18139.pdf [diakses 24 September 2018].

Häuser, Karl, 1966. "West Germany: "Foreign Tax Policies and Economic Growth", Foreign Tax Policies and Economic Growth. NBER: NBER and The Brookings Institution, pp. 97-164.

Nowossadeck, Sonja, et al., 2014. "Ageing in Germany: Content, Quality and Accessibility of Relevant Data Sources" [online] in https://www.dza.de/fileadmin/dza/pdf/Diskussionspapier_Nr_56.pdf [diakses 31 Agustus 2018].

Statistisches Bundesamt, 2015. "Age Structure of the Population of Germany" [online] in https://service.destatis.de/bevoelkerungspyramide/index.html $\#$ ! $\mathrm{y}=2015 \& \mathrm{v}=3 \& \mathrm{l}=\mathrm{en} \quad[$ diakses 1 April 2018].

Statistisches Bundesamt, 2018. "Employment" [online] in https:// www.destatis.de/EN/FactsFigures/NationalEconomyEnvironment/LabourMarket/Employment/Employment. html\#Tabellen [diakses 26 November 2018].

World Education Services, 2017. "Lessons from Germany's Refugee Crisis: Integration, Costs, and Benefits" [online] in https:// wenr.wes.org/2017/o5/lessons-germanys-refugee-crisis-integration-costs-benefits [diakses 3 Desember 2018].

\section{Artikel Daring}

Bölinger, Mathias, 2014. "Germany Profits from Immigration" [online] in https://www.dw.com/en/germany-profits-fromimmigration/a-18095858 [diakses 28 November 2018].

Connolly, Kate, 2016. "Angela Merkel defends Germany's refugee policy after attacks" [online] in: https://www.theguardian. com/world/2016/jul/28/merkel-rejects-calls-to-changegermanys-refugee-policy-after-attacks [diakses 4 Maret 2018].

Copley, C., 2016. "Refugees bring entrepreneurial spirit to riskshy Germany" [online] in http://www.reuters.com/article/ us-europe-migrants-germany-entrepreneurs-idUSKC- 
NoVA2D8. [diakses 8 September 2018].

Dettmer, Markus, et al., 2015. "German Companies See Refugees as Opportunity" [online] in http://www.spiegel.de/international/germany/refugees-are-an-opportunity-for-the-germaneconomy-a-1050102.html [diakses 26 November 2018].

Dettmer, Markus and Christian Reiermann, 2016. "Budget Battle Begins over Germany's New Residents" [online] in http:// www.spiegel.de/international/germany/budget-battle-begins-over-refugees-in-germany-a-1079864.html [diakses 28 November 2018].

Diw Berlin, 2015. "Population Ageing and Its Effects on the German Economy" [online] in https://www.diw.de/en/ diw_o1.c.514092.en/press/diw_roundup/populationageing_and_its_effects_on_the_german_economy.html [diakses 2 April 2018].

Dockery, Wesley, 2017. "Two years since Germany opened its borders to refugees: A chronology" [online] in http://www.dw.com/ en/two-years-since-germany-opened-its-borders-to-refugees-a-chronology/a-40327634 [diakses 4 Maret 2018].

Elliott, Larry and Julia Kollewe, 2011. Germany Faces Up to Problem of Ageing Workforce [online] in https://www.theguardian.com/world/2011/mar/17/new-europe-germany-retirement-pensions-exports [diakses 26 November 2018].

Hewitt, G., 2015. “Germany: Moral leader or misguided?” [online] in http://www.bbc.com/news/world-europe-34185970 [diakses 24 September 2018].

Huggler, Justin, 2014. "German Immigrants Bring in $£ 18 b n$ to the Economy" [online] in https://www.telegraph.co.uk/news/ worldnews/europe/germany/11259083/Germana-immigrants-bring-in-18bn-to-the-economy.html [diakses 28 November 2018]

KPMG, 2018. "Germany - Income Tax" [online] in https://home. kpmg.com/xx/en/home/insights/2011/12/germany-income-tax.html [diakses 28 November 2018].

Nasr, Joseph, 2015. "Germany needs migrants as workforce dwindles, but must pay for them" [online] in http://www.reuters. 
com/article/us-europe-migrants-germany-economy-idUSKBNoTT24Z20151210 [diakses 24 September 2018].

Scheller, Peter, 2014. "Expatriates: 10 Tax Issues to be Considered in Germany" [online] in https://scheller-international.com/ blog-beitraege/expatriates-10-tax-issues-to-be-consideredin-germany.html [diakses 28 November 2018].

Fakta Mengenai Jerman, n.d. "Demografi" [online] in https://www. tatsachen-ueber-deutschland.de/id/kategori/sekilas-pandang/demografi [diakses 20 Maret 2018].

Tzortzis, Andreas, 2004. "One Euro, One Way Out of Unemployment?" [online] in https://www.dw.com/en/one-euro-oneway-out-of-unemployment/a-1416143 [diakses 26 November 2018].

Wagstyl, Stefan, 2015. "Germany's Demographics: Young People Wanted" [online] in https://www.ft.com/content/b3oc8de44754-11e5-af2f-4d6eoe5eda22. [diakses 26 November 2018].

Wood, Vincent, 2017. "Majority of Germans claim they 'cannot take more refugees' after Merkel's open-door policy" [online] in https://www.express.co.uk/news/world/789416/GermanyMigration-migrant-crisis-angela-merkel-refugee-Syria-IraqAfghanistan [diakses 4 Maret 2018]. 